\title{
FIRST RECORD OF NEOSILBA (DIPTERA: LONCHAEIDAE) ON JATROPHA CURCAS L. IN BRAZIL
}

\author{
N. da S. Dias ${ }^{1}$, S.M.F. Broglio' ${ }^{2}$, D.S. Santos ${ }^{2}$, J.M. dos Santos ${ }^{2}$, P.C. Strikis ${ }^{3}$ \\ ${ }^{1}$ Embrapa, Agroindústria Tropical, Rua Dra. Sara Mesquita, 2270, CEP 60511-110, Fortaleza, CE, Brasil. \\ E-mail: nivia@cnpat.embrapa.br
}

\begin{abstract}
Neosilba spp. is firstly reported in physic nut fruits (Jatropha curcas), in Rio Largo, State of Alagoas, Brazil. A total of 438 specimens were found on 1,000 fruits between May and July 2010. Five species were recorded in the State of Alagoas: Neosilba zadolicha McAlpine \& Steyskal 1982, Neosilba glaberrima (Wiedemann, 1830), Neosilba certa (Walker, 1850), Neosilba pendula (Bezzi) and Neosilba bella Strikis \& Prado 2008. This is the first record of J. curcas as host plant of Neosilba in Brazil.
\end{abstract}

KEY WORDS: New host, physic nut, Tephritoidea.

\section{RESUMO}

PRIMEIRO REGISTRODE NEOSILBA (DIPTERA: LONCHAEIDAE) EM JATROPHA CURCAS L. NO BRASIL. Relata-se pela primeira vez a ocorrência de Neosilba (Diptera: Lonchaeidae) em frutos de pinhão manso (Jatropha curcas) no Município de Rio Largo, AL, Brasil. O total de 438 exemplares foi obtido de 1.000 frutos entre os meses de maio a julho de 2010. Cinco espécies foram registradas: Neosilba zadolicha McAlpine \& Steyskal, 1982 Neosilba glaberrima (Wiedemann, 1830), Neosilba certa (Walker, 1850), Neosilba pendula (Bezzi) e Neosilba bella Strikis \& Prado, 2008. Este é o primeiro registro de J. curcas como planta hospedeira de Neosilba no Brasil.

PALAVRAS-CHAVE: Novo hospedeiro, pinhão-manso, Tephritoidea.

Lonchaeidae are known as important pests of fruit trees cultivated in Americas. They are generally considered as secondary invader species as they attack fruits which were previously infested by Tephritidae (FEHN 1981; UCHÔA-FERNANDES et al., 2002; RAGA et al., 2004; BITTENCOURT et al., 2006). Currently, it is known that they can also be primary invader insects as they inflict direct damage on fruits and they can even be pests of some plant species reaching high infestation rates (ARAúJO; ZuCCHI 2002; SANTOS et al., 2004).

Thus, this study aimed to assess natural infestation by frugivorous flies in physic nut (Jatropha curcas L.) (Euphorbiaceae). For that, 1,000 fruits $(11.27 \mathrm{~kg})$ were collected from plants of experimental field at Centro de Ciências Agrárias da Universidade Federal de Alagoas, $\mathrm{AL}\left(12^{\circ} 40^{\prime} \mathrm{S}, 3^{\circ} 06^{\prime} \mathrm{W}\right)$, during frutification season which comprised the period between May and July 2010. Ripe fruits were transported to the Entomology Laboratory then weighed and deposited in trays containing autoclaved sand and covered by voile fabric. Puparia were placed on pots containing sand and closed with fabric for their emergence. Infestation rate was estimated based on the mean number of puparia/ $\mathrm{kg}$ of fruit and puparia/fruit.

After emergence from the pupas, it was obtained: 45 Neosilba spp. females, and they were identified as the following species: Neosilba zadolicha McAlpine \& Steyskal (72), Neosilbaglaberrima (Wiedemann) (111), Neosilba certa (Walker) (22), Neosilba pendula (Bezzi) (6) and Neosilba bella Strikis \& Prado, 2008.

Infestation rates were 53 puparia $/ \mathrm{kg}$ of fruit and 0,6 puparia/fruit. Although, the genus Neosilba has been considered as fruit secondary invaders by some authors, this work revealed that it is a primary exclusively association because Neosilba larva represented the only Tephritoidea species that were infesting J. curcas fruits.

Although, the genus Neosilba was the only obtained, there was a diversity of species and considerable level of infestation. In regions of Mossoró and Assu, Rio Grande do Norte, eight species of fruit were infested by Neosilba, however, the only species found was N. pendula, reaching the highest rate of

${ }^{2}$ Universidade Federal de Alagoas, Centro de Ciências Agrárias, Rio Largo, AL, Brasil.

${ }^{3}$ Universidade Estadual de Campinas, Departamento de Parasitologia, Campinas, SP, Brasil. 
infestationinfruitsjuá (Ziziphusjoazeiro-Rhamnaceae) with 21,1 puparia/ $\mathrm{kg}$ fruit (ARAúJo, 2002). This ratio shows the ability of various species of this genus to infect a single host.

This is the first record of J. curcas as the host plant of Neosilba in Brazil.

\section{REFERENCES}

ARAÚJO, E.L. Dípteros frugívoros (Tephritidae e Lonchaeidae) na região de Mossoró/Assu, estado do Rio Grande do Norte. 2002. 122 f. Tese (Doutorado em Ciências) - Escola Superior de Agricultura "Luiz de Queiroz", Universidade de São Paulo, Piracicaba, 2002.

ARAÚJO, E.L.; ZUCCHI, R.A. Hospedeiros e níveis de infestação de Neosilba pendula (Bezzi) (Diptera: Lonchaeidae) na região de Mossoró/Assu, RN. Arquivos do Instituto Biológico, São Paulo, v.62, n.2, p.91-94, 2002.

BITTENCOURT, M.A.L.; SILVA, A.C.M.; BOMFIM, Z.V.; SILVA V.E.S.; ARAÚJO, E.L.; STRIKIS, P.C. Novos registros de espécies de Neosilba (Diptera: Lonchaeidae) na Bahia, Brazil. Neotropical Entomology, v.35, n.2, p.282283, 2006.
FEHN, L.M. Coleta e reconhecimento de moscas das frutas em região metropolitana de Curitiba e Irati, Paraná, Brasil. Anais da Sociedade Entomológica do Brasil, v.10, n.2, p.209-238, 1981.

RAGA, A.; PRESTES, D.A.O.; SOUZA-FILHO, M.F.; SATO, M.E.; SILOTO, R.C.; GUIMARÃES, J.A.; ZUCCHI, R.A. Fruit fly (Diptera: Tephritoidea) infestation in citrus in the state of São Paulo, Brazil. Neotropical Entomology, v.33, n.1, p.85-89, 2004.

SANTOS, W.S.; CARVALHO, C.A.L.; MARQUES, O.M.; Registro de Neosilba zadolicha McAlpine \& Steyskal (Diptera: Lonchaeidae) em umbú-cajá (Anacardiaceae). Neotropical Entomology, v.33, n.5, p.653-654, 2004.

UCHÔA-FERNANDES, M.A.; OLIVEIRA, I.; MOLINA, R.M.R.; ZUCCHI, R.A. Species diversity of frugivorous flies (Diptera: Tephritoidea) from hosts in the Cerrado of the state of Mato Grosso do Sul, Brazil. Neotropical Entomology, v.31, n.4, p.515-524, 2002.

Received on $8 / 4 / 11$

Accepted on 16/5/12 